\title{
Civil society, cosmopolitics and the net: The legacy of 15 February 2003
}

Joss Hands

Faculty of Arts, Law and Social Science, Anglia Ruskin University, Cambridge, UK 2006

\begin{abstract}
The Global demonstrations on 15 February 2003 against the impending invasion of Iraq were on an unprecedented scale, and generated a great deal of commentary and debate. One response was that of Jürgen Habermas, supported by Jacques Derrida, who in an article entitled, 'February 15th, or, What Binds Europeans Together: A Plea for a Common European Foreign Policy, Beginning in the Core of Europe', suggests the events may be a 'sign of the birth of a European public sphere' and used the occasion to launch a call for a common European foreign and defence policy. In response to that piece this article questions whether the events of 15 February can really be seen as such a birth date, and argues that what the demonstrations indicate is rather the maturing of a global civil society. The role of technology, specifically the Internet, in the organisation and form of the protests is ignored by Habermas in his analysis, and results in a blind spot towards the events, which misses some of its most important elements. Rather than calling for a common European foreign and defence policy we should be looking towards a 'double democratisation' on a global scale that reflects the significance of global civil society in the formal structures of a global parliament, and which must address technology as an important element in generating participation and deliberation amongst a global citizenry.
\end{abstract}


Keywords: global civil society; cosmopolitics; anti-globalization movement; European public sphere; Internet; 15 February 2003

The Response to 15 February 2003

On 15 February 2003 there was an unprecedented global expression of resistance towards a war yet to take place, but widely trailed and anticipated as an act of unjustified violence and an unlawful violation of the post 1945 global security system. The numbers marching throughout the world could only be estimated by the million, 'In hundreds of cities, including Damascus, New York, Athens, Seoul, Rome, Tokyo and Sydney, demonstrators marched.' (Jeffrey, 2003) Analysis of subsequent survey data suggests that in London alone 1.4 million individuals attended. (Gordon, 2003: 50) The scale and ubiquity of the marches, and just who it was that was marching, has been the subject of surprise, pride, cynicism and also posited as a theoretical quandary. As the reporting in the aftermath reflected, 'The surprise has been the altruism of the protesters, and the size of the vacuum they fill.' (Riddell, 2003) One of the main speakers at the London march, the Mayor of London, Ken Livingston, began his address by saying, 'I cannot tell you the pride I feel that as mayor of London I can officially welcome you here to this city in the biggest political demonstration in 2000 years of British history.' And part of this pride was rooted in the fact that, 'This is a microcosm of Britain, all classes, all races, all religions and all regions of Britain are represented here.' (Livingston, 2003) This claim is borne out by 
quantitative empirical evidence, which shows a wide socio-economic spread of participants, with a particular involvement of what could be called 'unusual suspects'. In his analysis David Gordon concludes, 'The government's views on the war with Iraq may have succeeded in galvanising the politically dispossessed into political action.' (2003: 50)

At the same time what was doubly remarkable about the occasion was that it was not simply a British event, or a European event, but a global one. The nature and extent to which we can consider the protests to be a transnational constellation of actors has been one of the central subjects of subsequent discussions. One theoretical framework that has been mobilised in addressing this question is that of the public sphere, indeed the question of whether this remarkable event can be seen, or understood, in that context has been raised by one of the foundational figures of the modern concept, Jürgen Habermas. In an article originally published in the German Newspaper, Frankfurter Allgemeine Zeitung and translated in the Journal $\underline{\text { Constellations }}^{\mathrm{i}}$, Habermas makes the claim that:

The simultaneity of these overwhelming demonstrations - the largest since the end of the Second World War - may well, in hindsight, go down in history as a sign of the birth of a European public sphere. (Habermas, 2003: 291)

This possibility opens up a wealth of further questions and theoretical arguments. However, Habermas does not develop the idea here, but rather takes this as a starting place of a call for a common European foreign policy, including a single foreign minister. He argues that Europe, having found a voice, is now more aware of 
the failure of such a voice to be reflected formally, thus, 'the war made Europeans conscious of the failure of their common foreign policy.' (Habermas, 2003: 292) Thus the move to a common foreign policy, he argues, is necessary in order to, 'counterbalance the hegemonic unilateralism of the United States.' (Habermas, 2003: 293) The roots of this demand lie in Habermas' work on cosmopolitanism. His position on European integration is well known and is rooted in strengthened regionalism and global affiliations and norms without a move towards a world authority. His argument relies on the conceptual impossibility of democracy on a global scale with no outside against which to identify a community. (Habermas, 2001: 108-9) The way forward is therefore one that reflects elements of a two track democratic model, containing both a public sphere and a set of democratically accountable authorities, as the essay of the same name suggests a, 'Postnational Constellation.' The most obvious actually existing model of which, that reflects at least a set of nascent possibilities in that direction, is of course the European Union.

The argument offered in his article thus builds on these positions to suggest the need to include a 'a common security policy, and a common defence policy.' (Habermas, 2003: 292) Arguing that as the core countries become more unified they will 'hold the door open' to the more sceptical and as it expands, 'the more capable the core of Europe becomes in effective action externally'. (Ibid.) It therefore seems hardly surprising, when considering the call for these state like qualities in the EU, that Habermas would like to see the emergence of a European Public sphere as a way of adding a democratic legitimacy to such developments, and thus takes the events of 15 February as a sign of such. I will argue below that this is problematic, and offer an 
alternative perspective.

\section{February, the Birth Date for a European Public Sphere?}

Habermas' does not make the claim directly that 15 February heralds a new European public sphere, in fact he uses the phrase, 'sign of the birth of a European public sphere' (Habermas, 2003). However, because it is not realistically possible to distinguish a 'sign' from the early development of the thing itself; it is difficult to see how a sign could be other than an interpretation of actual events, I will treat these claims as coterminous. Further than this he uses the supposition as a stepping-stone towards the call for a common European foreign policy, legitimated by the attendant shared European interests and as such this 'sign' must be considered fundamental to his demand for other commonalities.

It is therefore worth questioning whether the events really were constitutive of a public sphere, even if in an early stage. The prerequisites for what could be classified as a European public sphere have been widely discussed, and some of the key requirements found wanting. For example, one central element often cited is a Europe wide media system that engages consistently with trans-European issues and, as Habermas' concept itself requires, is capable of holding the state or government to account. (Calhoun, 2003; Van De Steeg, 2002) However it has been pointed out with regard to Habermas' own efforts in this area, of which the Frankfurter Allgemeine Zeitung article was one component of an attempt to generate a pan-European debate, that 'Despite its grandiose pretensions, the Habermas Initiative has become a striking 
example of the difficulties confronting the modern Babylon that goes by the name of Europe.' (Fredriksson, 2004: 3) Fredriksson goes on to remind us of the failure of The European newspaper, as an 'escapade that lasted hardly a decade [and] lost an estimated 70 million pounds.' (Ibid.)

On an even more elementary level the concept of a European public that could be considered to match the ideal-typical modes of communication, entailed by Habermas' theory of communicative action, hits a set of problems that emerge from the multi-lingual and multi-cultural nature of Europe. A shared public sphere requires a shared language, a shared interest and thus a shared identity. As Craig Calhoun has argued, 'To speak of an interest in European integration, thus, is to enter a discussion in which establishing the identity (or identities) of relevant actors is crucial.' There is, 'no escape from the need to establish identity at some level in order to establish interests.' (Calhoun, 2003) Thus the prerequisite for Habermas' argument for a common approach needs to surmount these hurdles. I shall discuss each of these points in turn, before returning to the specifics of 15 February 2003.

Firstly the requirement of a common language within the multi-lingual nature of European societies would seem a major barrier to this cause.

However, it is clear that multi-lingual democratic polities do exist within existing states. There is also a strong case to suggest that, at the least, a multi-lingual public sphere is not conceptually contradictory. As Marianne Van De Steeg points out, 'Since the media is the intermediary between the actors in the debate each can speak 
his/her language and still communicate with the others.'(2002: 504) I will not develop this argument here; it is enough to conclude for now that a common language need not define the boundaries of public discourse.

Habermas therefore needs to clear the second hurdle, a common identity, which would provide the required European boundary for shared interests. While such boundaries are enough of a problem within existing states the building of a shared European identity raises its own peculiar challenges. It is therefore not surprising that a central issue addressed by the article is that of, as one element of the title suggests, 'What Binds Europeans Together'. This needs to be done without having to rely on the overarching conception of nationhood, the usual unifying concept. Therefore Habermas calls on the shared history of the peoples of Europe and the values that have emerged, in no small part out of what we might call violence fatigue, and towards a tolerant democratic polity and cultural diversity. He claims that this capacity for toleration, 'can also become a feature of a common identity.' (Habermas, 2003) Included in the basket of European characteristics he offers a range of values such as faith in the state over the market; welfare state ideals; liberty of the person; desire for a safe multilateral international order.

I want to raise two key objections to these claims: firstly that many, if not all, of these features are not particularly European at all; secondly that many of them are not actually true in practice.

With regard to the first objection Habermas does admit that many of the values he associates with a European identity are in fact recognizable throughout the world, but largely because it is European civilization that has spread throughout the world, he 
asks, 'haven't the historical achievements of Europe forfeited their identity forming power precisely through the fact of their worldwide success?'(Habermas, 2003: 294) Included in this 'power' are Roman law, urbanization, democracy and human rights, secularization of state and society. Of course we might want to add slavery and environmental destruction amongst others. Yet despite this Habermas sees a singular set of predicates still attached to a European-ness that allows the non-European to identify citizens of many and various nations as European. For example, he talks of the common trust in the state and suspicion towards markets and technological progress, as well as resistance to the use of force against individuals. This basket of claims, while in question after 1989 are now shown to be in tact, "February $15^{\text {th }}$ shows that the mentality has survived the context from which it sprang"(Habermas, 2003: 296). However to imagine that such qualities are somehow European by definition is to ignore the global presence of such values in many indigenous forms within social movements, communities and political struggles, if not always in governance and law. This view of Europe's current place in the world is at best rosy, and perhaps essentialist, and could even be characterised as a kind of European jingoism.

This leads into my second objection that Habermas' claims are not actually true in practice, certainly not at the level of European institutions and governments. Habermas claims that the EU as a formal body is an exercise in the 'domestication of state power' (ibid.) while at the same time suggesting a common foreign policy is a way of resisting US hegemony. He sees this as reflecting the tolerant and cosmopolitan characteristics embedded in the European identity. While Habermas sees this counterweight to the US in economic and diplomatic terms by arguing that 
such an arrangement might help us on the way to, 'a mutual limitation of sovereignty, on the global as well as the national-state level', (ibid.) he may well only be justified by wishful thinking, particularly when implied in his argument is a buried urge for Europe to flex its muscles against a rampant United States. Indeed it would be a very rare occasion in history if Europe was able to exercise increasing economic and political power without expanded military power following close behind.

This raises the possibility that Europe might look like a cosmopolitan state from the inside, and indeed as such would be desirable and beneficial to those insiders, but would appear to outsiders as little more than a conventional armed to the teeth threatening and self-supporting state. If we were to view 15 February as part of that context then perhaps we would be justified in calling it a new European public sphere, other objections aside, and thus as a way of strengthening the claim for Europe's internal democratic credentials and acting as America's 'other'. Yet the condition for a European identity, as tolerant and cosmopolitan and oriented towards a commitment to security on a global basis, can be further questioned in empirical terms. A recent Amnesty International report testifies that,

\section{EU arms, security equipment and services are contributing to grave human rights abuses and the scale of potential abuse is now enormous. The major EU arms exporting countries - France, Germany, Italy, Sweden and the United Kingdom - account for one third of the world's arms deals. (Amnesty, 2004)}

Neither is this a problem that exists at the level of the nation states but is part 
of the legal framework of the EU, as Amnesty locates the fault with, "serious flaws in the European Union's key arms control agreements, especially the 1998 EU Code of Conduct on Arms Exports." (Ibid.) Again we see serious questions raised in the relationship of the EU with countries that have poor human rights records and are far from the 'acknowledgement of differences.' With the case of Turkey, widely condemned for abuses of ethnic minorities, women and political dissenters, lip service towards high ideals may be made but,

Foreign governments, reluctant to develop the good work of the UN Special Rapporteurs, the ECPT and other expert bodies, are keen to see token improvements in human rights protection which will excuse them from firm action. (Amnesty, 1996)

And again European institutions are not except from this condemnation,

The Council of Europe's monitoring body, the ECPT, has investigated and reported on the prevalence of torture in Turkey, but the Councils Committee of Ministers itself has taken no further action on human rights violations in Turkey for more than a decade. (Amnesty, 1996)

All the above, plus of course the Support of the UK, Spain, Italy, The Netherlands, Denmark, Poland and others, for the illegal invasion of Iraq would lead us to severely question, 'the moral basis of politics' (Habermas, 2003) within at least large elements of Europe; several of which must be considered, in Habermas' words, 
to be part of its 'core'. There are, of course, other cases that relate to both member states and European institutions that certainly give us reason to question any such moral basis that in any way distinguishes Europe from the rest of the world. This is not to downplay the EU's highly successful achievements internally in generating a rights culture, of economic success, protection of labour conditions and so on, but it begs the question as to whether the EU is really such a cosmopolitan and progressive force in the world.

Finally there are strong shared interests within Europe with regards the welfare system, labour rights etc., though these are certainly not uncontested. However these interests are not connected with European identity or language but can be categorised as general human interests. They are tied to a Europe only through its institutions, but their definition as European is entirely procedural; i.e. one's membership provides a set of rights that reflect a shared conception of interests. It is then difficult to see how these interests are specifically European and therefore how they could contribute to an identity, other than they happen to be guaranteed by the institutions of the EU. This is inevitably connected to the boundedness of Europe, but only because it is exactly through excluding others from our institutions that their membership is clear, in other words its criterion is an economic and not an identity issue. There thus appears a contradiction between the interests of toleration, justice etc. and the need to keep Europe exclusive. As such Habermas' definition of European identity cannot be true. This has not gone unnoticed in the literature on European Identity, as Bo Stråth has observed, 
The inclusion of European insiders implies the exclusion, by whatever criteria, of non-European or not-yet European 'outsiders'. Thus, humanistic ideals such as equality, freedom and pluralism have come into conflict with the need to exclude. (Strath, 2002: 398)

These arguments cited above all point towards a rejection of the logic that 15 February could have been a European public sphere, in the sense of representing a unified voice or a shared European identity and interests. I will first make an alternative interpretation of the events, and then offer an explanation as to why I think Habermas came to the conclusions he did.

\section{February and Global Civil Society}

The format, practice, dissemination of information and organisation of 15 February resembles features associated with what has come to be known as the global justice movement, or by the misnomer of the anti-globalization movement, but what has also been termed the movement of movements. The often-cited roots of this can be traced to the emergence of the Zapatistas from the Chiapas region of Mexico in 1994, coinciding with the inauguration of NAFTA (North American Free Trade Agreement) their aim not to take power but to contest power. (Castells, 2004: 75-80; Hardt \& Negri, 2004: 85; Kaldor, 2003a: 102; Sklair, 2002: 278)

The Zapatistas use the language of civil society in a direct and knowing manner. In response to the looming Iraq invasion in early 2003 the web site Znet 
circulated a manifesto against the war. Sub-Commandant Marcos signed on behalf of the Zapatistas, and subsequently called on, 'civil society of Mexico and of the world to promote the knowledge, discussion, enrichment and signing of the manifesto,' and that, 'the right to rebellion, to defy those who oppress us with various alibis (always the gods of Power and Money with different masks), is universal.' (Marcos, 2003) Historically their mission has been to include, 'individuals, groups, collectives, movements, social civic and political organisations.' (Zapatistas, 1998: 14) And the list goes on to include all elements of civil society. It is from the Zapatista 'encounters' that the organisation People's Global Action emerged, a network coordinated through the Internet and the Web, and which has provided a template for many of the organisations that have followed it. Indeed in an empirical study carried out in this area hyperlink analysis revealed just how significant the Zapatista presence, at least on the Web, has been on a global scale, "Zapatista related sites are central to global NGO networks and help to bind them together."(Garrido and Halavais, 2003: 181) The connection between the emergent movement, the anti-war actions and the technology of the World-Wide-Web is more that passing, indeed many of the same organisations were directly involved and co-ordinated via its networks. What is also clear is the enormous range of those involved, who may be related to, but go way beyond, the nascent movement of the mid-nineties.

This characteristic is pivotal, as we must consider the nature of the marches not as the manifestation of a discursive process leading towards consensus but as an aggregation of overlapping interests. The sheer diversity of participants across the globe were self-evidently not sharing a specific set of localised reasons for action but 
rather, on a global level, the marches were coordinated through an orchestration of aims, which were loose enough to mobilise the common interests of all participants: peace, democracy and human rights, all made concrete by the injustice and illegality of the pending war.

In the language of social movement theory this has certain resonance with the 'SPIN' model developed by L.P Gerlach and V.H. Hines, a 'segmented, polycentric, integrated network'. (Bennett, 2003: 22) Some of the key characteristics of such networks being: the absence of hierarchical structures; fluidity of membership; multiplicity of hubs and non-formal ties. (Bennett 2003) Such formations have been recognised as present in the global justice movement, indeed almost definitional of it (Klein, 2002: 17; Hardt and Negri, 2004: 288), and were certainly at work on 15 February. Attendant to this is the centrality of the Internet, as Bennett argues, 'networks of diverse groups could not be sustained without the presence of digital communication channels.' (Bennett, 2003: 24)

The adequacy of the public sphere as an explanatory framework is clearly weak here, what the above represents would be closer to Nancy Fraser's conception of a collection of counter publics than the more unitary Habermasian approach. (Fraser, 1992) Or what Jeffrey C. Alexander has called a "fragmented public sphere". (1998: 8). However, whenever the notion of a public sphere is used in this way, i.e. noninstitutional and retained across such wide terrain, its definitions become so porous and weak as to make it indistinguishable from the overlapping of aggregated interests that would be a more apt description of the kinds of social movements mentioned above, and subsequently of civil society itself. 
When we consider contemporary definitions of civil society this problem becomes acute. For example, Michael Walzer defines civil society as, 'the space of uncoerced human association and also the set of relational networks - formed for the sake of family, faith, interest, and ideology that fill this space.' (1995: 7) And Jean Cohen and Andrew Arato claim that, 'social movements constitute the dynamic element in processes that might realise the positive potentials of modern civil societies.'(1992: 492) To try and marshal notions of the public sphere to grasp these movements is therefore likely to lead to a misunderstanding of their dynamic and novel nature.

In the global context within which this activity is taking place I believe what was witnessed on 15 February can only really be grasped within a theory of global civil society. Mary Kaldor argues that the modern conception of which has come to incorporate the development of identity politics and thus even includes elements of the family and areas previously considered located exclusively in the private sphere (2003a). The central idea is a commitment to what Habermas would describe as communicative action, but without the formal elements that require an end goal of consensus; more simply reading books, talking and building of networks of sympathy. Thus without having a demand to seize power one can still 'change the relationship between state and society.' (Kaldor, 2003a: 57)

Kaldor highlights the transnational nature of these movements; which include the connecting up of the anti-nuclear movements across Europe, solidarity movements against apartheid in South Africa, dissident movements in Eastern Europe, and Latin American Civil Society. In the aftermath of 1989 this global civil society, which 
represents, 'a radical extension on both political and personal rights - the demand for autonomy, self-organisation or control over life', (Kaldor, 2003a: 76) has come to be reflected, and influenced in turn, by the movements discussed above and certainly manifest in the global events of 15 February. Also of great significance, as Kaldor makes clear, is the role of the emergent network society as the glue of global civil society, for example the place of what she calls 'transnational civic networks' that connect INGOs with social movements and grass roots organisations. This she acknowledges, via Manuel Castells, as, 'the new social morphology.'(Kaldor, 2003a: 95)

While I cannot explore it further here the nature of such mediated network coordination, which has come to underpin global civil society, is profoundly important and represents a vital area of ongoing research. (Castells, 2004; Hardt and Negri, 2004; Reingold 2002; Kahn and Kellner 2004; Dyer-Witheford, 2004)

Nevertheless it needs to be noted that the nature of global civil society, and the mobilisation of network technology, has not gone uncontested. For example Jean Grugel points out that, 'its strong normative underpinnings can easily lead to an exaggeration of transformative capacity of transnationalised collective action and overstate the real opportunities for change.' (Grugel, 2003: 276) And secondly Grugel identifies a 'dark side', namely that, 'anti-democratic movements are also globally active and have taken advantage of the opportunities offered for transnational networking.' (277) ii

Objections not-withstanding what all of these approaches have in common is, of course, a central address to the mode of information in the globalized 
communication infrastructure. It is precisely Habermas' attitude to technology that provides an explanation as to why he makes the claims he does about 15 February, and leads him to ignore it as a factor in his interpretation and subsequent prescriptions.

\section{February, the Absence of a Technological Dimension in Habermas' Approach}

At the centre of Habermas' theory of communicative action $(1984,1987)$ is the attempt to re-conceptualise the process of reason and rationalisation. One key aspect of his reconstruction of communicative pragmatics is the delineation of communicative domains. He categorises the domain of external nature as distinct form internal nature and society. External nature, as expressing the objective world, requires a cognitive objectivating attitude in which truth is decided by a successoriented attitude towards nature. This is characterised as technical instrumental communication, and in order to be controlled needs to be contained or bounded within the norms and values of the domains of internal nature and society. The problem arises when it is de-coupled in the development of modernity, and comes to colonise the other domains of reality that are expressed with other attitudes, the expressive and performative.

Andrew Feenberg argues that Habermas, by delineating these domains and placing technology as purely instrumental, means it, 'will always be in a non-social, objectivating relation to nature, oriented towards success and control.'(Feenberg, 1999: 157) Logically in this framework the only way to respond to technology is to 
contain it to its appropriate domain, to resist the colonisation of technological rationality that is embodied in technology itself. We can clearly see this in his descriptions of the decline of the public sphere through the successive waves of technologisation and mediation of public discourse (Habermas, 1989). Feenberg argues that Habermas therefore underplays the role and the potential for the social shaping of technology, primarily because, 'The Habermasian position confuses the abstract level of pure technical principles with that of concrete social reality...This confusion leads plausibly to the claim that science and technology are nonsocial.'(Feenberg, 1999: 163)

The problem is exacerbated by his failure to address the question of technology outside of his critique of the steering media of money and power in capitalist economies; he does not class technology as a separate media. Feenberg puts this down to the view that, as technology is ubiquitous within the system then, 'technology's contribution to the problems of modern society could be adequately captured by analysis of its employment in the market and administrative structures through which the colonization process advances.'(Feenberg, 2004: 5) The result is that, "the theoretical disadvantages of thus dissolving technology into economics and politics far outweigh the advantages.' (Ibid.) One such disadvantage is clear to hand here, namely he does not perceive the role of technology in helping forge a civil society that transcends, or at least helps to resist, the very colonisation process he has identified. This means there is no way of contributing to the goal of a global civil society that employs technology to help construct a 'parallel polis' and to 'put politics in its place and make sure it stays there.'(Kaldor, 2003a: 57) 
Given such a blind spot this may well explain why it is that he does not see beyond the immanent publicness of the streets on 15 February into the networks that have nourished and given form to the protests, actions and discourse that, in many ways, could be described as epiphenomena of the 'new social morphology'. When Howard Rheingold describes the forms of collective action coordinated through new mobile telecommunications and computer mediated communication he describes a crowd that is, 'The coordinated movement of schools and flocks in a dynamically shifting aggregation of individual decisions.' (Rheingold, 2004: 200) Such a description seems a far more appropriate one than the rather formal and procedural mechanisms of a public sphere, as well as coinciding more effectively with the context of a global civil society as discussed above. When considering the forms of the anti-war and global justice movement to ignore the role of technology and networked interactions is to miss a significant factor.

One lesson to be drawn from this is that offering resistance to American hegemony should not focus on the strengthening of a European counterweight identifiable by a spatially defined territory and specific polity, which in itself is a dangerous move towards reconstituting the structures of a cold war style adversarial politics. Rather we should look towards the force of what has been described as the second global superpower: civil society, which will of course include its internal US contingent, of whom there was a significant presence on 15 February, and again in great numbers on the streets of New York in August 2004. Such forces, working in concert with the global community, surely have the capacity to re-orient the United States from within. The only sane approach is to allow civil society to do what it does 
best, be chaotic, open and democratic. This is the genius and the inspiration of 15 February.

\section{Representing Global Civil Society}

One of the drawbacks of placing faith in global civil society, and recognising its at least partially technologically mediated frameworks of communication, is that in terms of distribution, access and control it is at best patchy. As such it is thus clearly limited in formal democratic terms. While it can be considered deliberative in practice, at least as far as social movements and grass roots organisations use it, less so by NGOsiii, it clearly is not embedded in formal democratic procedures. In order for global civil society to translate into a force for democratic empowerment and change we need to see what David Held has called, 'double democratisation', i.e. the democratisation and restructuring of both civil society and the state in order to ensure active citizens and a containment of the power of global capital. (Held, 1995) Yet this needs to take place outside the traditional centres of national power, for reasons discussed above. This is a call that is widely recognised, including by Habermas, whose commitment to cosmopolitan democracy had led to his notion of a 'global domestic policy... without world government.' (Habermas, 2001: 108) However his vision is built around bargaining between governments, where the processes of intergovernmental relations are made present to national public spheres. So we have a, what we might call, three-track model of democracy. Yet the third intergovernmental level assumes a distance from its constituency that stretches the term democracy 
beyond a representative form that is the norm in the liberal constitutional context it is commonly used. To put it bluntly this means there is no procedure available to a global civil society to directly limit global governance in such a form, or indeed to throw it out.

The answer must be that global civil society needs global security and global political representation. Mary Kaldor concludes that achieving global security, or at least minimising violence, can only be, 'through the extension of global rules based on consent' and thus, 'International law needs to be strengthened.' (Kaldor, 2003a: 156) and to apply this we need available troops, police, civilians and others. In line with the argument presented above I would argue that the element of consent could only be legitimated through a combination of global civil society and some form of global political representation. The form that such representation would take is of course exceptionally difficult, and here I can do no more than sketch a possibility.

David Held, while sharing many of Habermas' views, goes beyond them and has argued that the United Nations could be the starting place; initially just fully enforcing its charter and then extending it to include features such as the General Assembly becoming a recognised legislative chamber, where near unanimous votes would legitimate international law; also the abolition of the security council veto system. (Held, 1995: 269) Such a set of staged changes could hugely strengthen its presence and legitimacy. However, Held also argues for longer term goals, for a full system of cosmopolitanism that would, 'require the formation of an authoritative assembly of all democratic states and agencies.' (Held, 1995: 273) And vitally, as far as reflecting civil society goes, 'The establishment of an independent assembly of 
democratic peoples, directly elected by them and accountable to them.' (Ibid.)

This view is reflected by Richard Falk and Andrew Strauss, who have proposed the idea of a Global People's Assembly (GPA) (2001). Similarly, from an activist perspective, George Monbiot has mapped out a proposal for a global system of representation (2003). The value of such a body means it could trump states in certain globally significant areas, and go beyond the United Nations as an interstate mechanism, and in doing so represent the interests of a specifically global civil society in ways that states, even acting together, could not. Thus it could work to secure, for example, global environmental standards and economic justice. Of course the idea has been submitted to a number of criticisms, for example key objections summarised by Jean Grugel suggest that, 'Cosmopolitanism seems to offer a globally extended form of liberal governance without attending to questions of cultural (or other forms of) difference or addressing the need to redistribute power in anything other than a territorial sense'. (Grugel, 2003: 270) His latter point is reflected in an argument developed by Tony Smith who, with specific reference to David Held, claims that, 'capitalist property and production relations are of overwhelming significance. They ultimately prove incompatible with the democratic values Held seeks to advance.' (Smith, 2003: 8) While I do not have the space to unpack these objections in depth it is worth offering two counter arguments in defence of a cosmopolitan vision.

First, with regard to cultural diversity, the implication that global democracy would invoke a diminution of cultural difference is a priori mistaken. Such a position invokes a cultural relativism against the notion of a universal human rights that 
ascribes difference where it not to be found. Seyla Benhabib, in her book The Claims of Culture (2002) argues compellingly that we should not seek to reify cultural difference but recognise it as an ongoing negotiation in which a balance is struck between recognition of the other as such, and recognition of identity wherein, 'The "other" is always also within us and is one of us.' (8) Thus, 'the task of democratic equality is to create impartial institutions in the public sphere and civil society where this struggle for the recognition of cultural differences and the contestation for cultural narratives can take place without domination.'(Ibid.) It seems to me that on a global scale a world parliament would be just such an institution.

Secondly, with regard to issues of redistribution, the demands that are implied in such objections as cited above would lead to the need for a world state, not simply a global parliament, and therein lies the potential for a very real and dangerous centralising of power. Yet regardless of how desirable or not such a change may be broader issues of redistribution are not incompatible with cosmopolitics, indeed it is arguable that they are in fact implied by it. For example, Amy Gutmann and Dennis Thompson argue that in order for the deliberative processes of democracy to be fully effective they need to take place against the background of the satisfaction of basic needs or what they refer to as, 'the basic opportunity principle' (1996: 273). While there may well be strong arguments to even go beyond this principle at the very least if we posit the need for a global parliament to represent global civil society, then embedded in it lies the obligation to provide a global set of basic opportunities. As such this body would provide a moral driving force against which the inequities of power and wealth would stand in sharp relief. 
Beyond this a global parliament could contribute towards the central task of strengthening the role of global civil society in many other ways that would reduce the weight of the criticisms suggested above. Specifically, in the context of this article, through an account of the network technologies discussed previously. Given the significant role of the Internet in forging global civil society the harnessing of its potential to enrich a global parliament is strong.

In turn a parliament, given the power to do so, would be in a position to contribute to the 'double democratisation' Held calls for by addressing issues surrounding the digital divide, by contributing to the redistribution of technology and know how on a global level. Further than this a valuable, and necessary, route to democratisation may well be in a encouraging, or legislating for, the embodiment of democratic technical codes into the fabric of technology (Feenberg, 2002), specifically by containing the interests of capital and its anti-democratic and colonisation tendencies, visible in current Internet development (Dahlberg, 2004).

One effect of this would be to make it easier to, 'bound the economy by other logics.' (Feenberg, 2002: 142) Thus the prioritising of values that might include education as a value in itself, the transformation of work processes to include the needs of labour and maximisation of worker autonomy, the prioritising of environmental considerations and so on. All of these changes would be difficult to conceive as happening on anything other than a global scale via the pressures of a networked global civil society embodied through a globally representative parliament.

The role of a global parliament could thus include specific responsibilities to maximise such values, for example as an initial step, taking democratic control of the world-wide-web consortium, which while generally sympathetic to open-source and 
widening of access is still essentially an elite operation, similarly ICANN (Internet Corporation for Assigned Names and Numbers) could be returned to the public sector and be subject to a specifically shared public interest. Also by adopting alternative codes for the measuring of economic and technological success beyond efficiency the goals of developers could be shifted and steered away from the prioritising of market values.

These questions are by no means nebulous or utopian, indeed are on the agenda of, for example, the World Summit on the Information Society (WSIS). Ralf Bendrath, at the first round of the WSIS process, made the point at the civil society plenary that, 'there must be a creative use of ICTs to ensure civil society participation from all over the world', and that there were positive developments which meant, 'a major step forward in developing a multi-stakeholder process on the global level. For the first time civil society and others have participated,' but at the same time, "Our speaking slots only amount to 2.7 per cent of the total plenary time!' (2004)

The role of civil society in that process, and in global governance more widely, is thus vital, and needs to be defended in order to make possible the kind of double democratisation discussed previously. That would be precisely the counter weight to the American hegemony that Habermas sees in the hope of 15 February, but unlike his reading of it as a spur to generate a European official opposition, with no democratic stake in the US, the combination of global civil society and a global parliament would be a powerful brake and not a provocateur.

Indeed, even without political representation on a global scale, we have still to see the full effects of 15 February played out. The legacy of the global movement, the aggregated, networked smart crowds of 15 February, may well be found in the phrase 
invoked and repeated in their many languages, that 'this is what democracy looks like'. I believe that what we witnessed on 15 February was not the birth of a European public sphere but another step forward for a global civil society for which democracy is not just a matter of better schools and roads, but global justice, universal human rights, a belief that there is such a thing as society, and that our solidarity must extend to the people our governments and corporations bomb, exploit and poison. 
${ }^{i}$ The article was co-signed by the late Jacques Derrida, who while not responsible for writing the document wanted to share its sentiment.

ii These are important reasons as to why I call for a 'double democratisation' in the section 'Representing Global Civil Society'.

iii For an example of the way in which NGOs operate on line see Eugenia Siapera's discussion of asylum seekers use of the Web (2004).

\section{References}

Alexander, J. C (1998) 'Civil Societies Between Difference and Solidarity, Rethinking Integration in the Fragmented Public Sphere', Theoria 92: 1-14

Amnesty International (1996) 'Turkey: No Security Without Human Rights' on-line. Available <http://web.amnesty.org/library/index/ENGEUR440841996\#GFT> (10 July 2004)

Amnesty International (2004) 'EU Arms Exports Threatening Global Security' on-line. Available: $<$ http://web.amnesty.org/library/index/engpol300242004> (10 July 2004)

Bendrath, R (2004) ' 25 June 2004 - Observers (Civil society): Heinrich Böll Foundation' on-line. Available: < http://www.itu.int/wsis/> (15 August 2004)

Bennett, W. Lance (2003) 'The Internet and Global Activism'. in N. Couldry and J. Curran (eds.) Contesting Media Power, Oxford: Rowman and Littlefield

Blumer, J.G \& Gurevitch, M (2001) 'The New Media and Our Political Communication

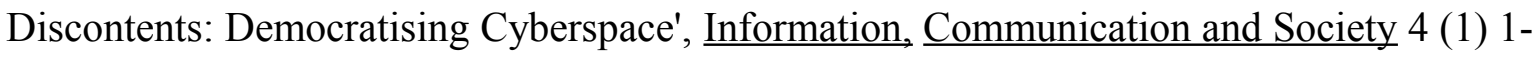
13

Calhoun, C. (2003) 'The Democratic Integration of Europe: Interests, Identity and the Public Sphere' .in M. Berezin and M. Schain, M. (eds.) Europe Without Borders, Baltimore: Johns Hopkins University Press

Castells, M. (2004) The Power of Identity $2^{\text {nd }}$ Ed, Cambridge: Polity Press

Cohen, J. and Arato, A. (1992) Civil Society and Political Theory, Cambridge MA.: MIT Press 
Cohen, R and Rai, M (Eds) (2000) Global Social Movements, London: Athlone Press

Dahlberg, L (2001) 'Democracy via Cyberspace, Mapping the Rhetorics and Practices of Three Prominent Camps', New Media and Society (3) 2: 157-177

Dahlberg, L (2004) 'Cyber-Publics and the Corporate Control of Online Communication', Javnost/The Public 11 (3): 77-92

Dyer-Witheford, N (2004) 'Species-Being Resurgent', Constellations 11(4): 476-491

Falk, R. and Strauss, A. (2001) 'Towards a Global Parliament', Foreign Affairs (80) 1

Feenberg, A. (1999) Questioning Technology, London: Routledge

Feenberg, A. (2002) Transforming Technology, Oxford: Oxford University Press

Feenberg, A. 'From Essentialism to Constructivism : Philosophy of Technology at the Crossroads' on-line. Available: <http://www-rohan.sdsu.edu/faculty/feenberg/talk4.html > (20th February 2004)

Fine, R. and Smith, W. (2003) 'Jürgen Habermas' Theory of Cosmopolitanism', Constellations 10 (4): $471-487$

Fraser, N (1992) 'Rethinking the Public Sphere: A Contribution to the Critique of Actually Existing Democracy'. in C. Calhoun (ed.) Habermas and the Public Sphere, Cambridge, MA: MIT Press

Fredriksson, C. 'Energizing the European Public Space', on-line. Available: $<$ http://www.eurozine.com> (12th July 2004)

Garrido, M. and Halavais, A. (2003) 'Mapping Networks of Support For the Zapatista Network'. in M. McCaughey and M. Ayers (eds.) Cyberactivism: Online Activism in Theory and Practice, London: Routledge

Gordon, D (2003) 'The Cost Consequences and Morality of the War in Iraq', Radical Statistics Issue 84, on-line. Available: http://www.radstats.org.uk/no084/ (8 April 2005)

Grugel, J (2003) 'Democratisation Studies Globalisation: The Coming Age of a Paradigm', British Journal of Politics and International Relations 5 (2): 258-283 
Gutmann, A and Thompson, D (1996) Democracy and Disagreement, Cambridge MA.: Harvard University Press

Habermas, J. (1984) Communication and the Evolution of Society, Cambridge: Polity Press

Habermas, J. (1984) The Theory of Communicative Action Vol.1, Reason and the Rationalisation of Society, Cambridge: Polity Press

Habermas, J (1987) The Theory of Communicative Action Vol. 2, The Critique of Functionalist Reason, Cambridge: Polity Press

Habermas, J. (1989) The Structural Transformation of the Public Sphere, Cambridge: Polity Press Habermas, J. (2001) The Postnational Constellation, Cambridge: Polity Press

Habermas, J. (2003) 'February 15, or, What Binds Europeans Together: A Plea for a Common European Foreign Policy, Beginning in the Core of Europe', Constellations (10) 3:291-297 Hands, J (2004) 'Living with e-Utopia: Camus, Habermas and the Politics of Virtual Dissent' .in J. Hands and E. Siapera (eds.) At the Interface: Continuity and Transformation in Culture and Politics, New York \& Amsterdam: Rodopi

Hardt, M. and Negri, A. (2000) Empire, Cambridge MA.: Harvard University Press

Hardt, M and Negri, A. (2004) Multitude, War and Democracy in the Age of Empire, New York: The Penguin Press

Held, D. (1995) Democracy and The Global Order, Cambridge: Polity Press Jeffrey, S (2003) 'UK's Biggest Peace Rally' The Guardian Unlimited, 15 February on-line. Available: http://www.guardian.co.uk/antiwar/story/0,,896475,00.html (1 April 2005) Kahn, R and Kellner, D (2004) 'New Media and Internet Activism: From the "Battle of Seattle" to Blogging', New Media and Society 6 (1) 87-95

Kaldor, M. (2003a) Global Civil Society, Cambridge: Polity Press

Kaldor, M. (2003b) 'The Idea of Global Civil Society', International Affairs 79 (3): 583-593

Klein, N (2002) Fences and Windows, London: Flamingo

Livingston, K. (2003) 'Ken Livingston Hyde Park Speech' BBC 15 February, on-line. Available: 
http://news.bbc.co.uk/1/hi/uk/2767427.stm (15 February 2003)

Lyotard, J. F. (1979) The Postmodern Condition: A Report on Knowledge, Manchester: Manchester University Press

Marcos 'Zapatistas Statement on 'We Work for Peace and Justice' Znet, on-line. Available: $<$ http://www.zmag.org/znet.htm> (5 April 2003)

Monbiot, G (2003) The Age of Consent, London: Flamingo

Rheingold, H. (2002) Smart Mobs: The Next Social Revolution, New York: Basic Books

Rheingold, H. (2004) 'Smart Mobs'. in H. McCarthy, P.Miller and P. Skidmore (eds.) Network Logic: Who Governs in an Interconnected World, London: Demos

Riddell, M. (2003) 'The Great Unheard Finally Speak Out' The Observer, 16 February

Sklair, L (2002) Globalization, Capitalism and its Alternatives, Oxford: OUP

Smith, T (2003) 'Globalisation and Capitalist Property Relations: A Critical Assessment of David Held's Cosmopolitan Theory', $\underline{\text { Historical Materialism }} 11$ (2): 3-37

Strath, B. (2002) 'A European Identity: To The Historical Limits of a Concept', European Journal of Social Theory 5 (4): 387-401

Siapera, E. (2004) 'Asylum Politics, the Internet and the Public Sphere', Javnost/The Public 11(1): 79-100.

Van De Steeg, M. (2002) 'Rethinking the Conditions for a Public Sphere in the European Union', European Journal of Social Theory 5 (4): 499-519

Walzer, M. (1995) Towards a Global Civil Society _Oxford: Berghahn Books

Webster, F (ed) (2001) Culture and Politics in the Information Age, London: Routledge Zapatistas (1998) Zapatista Encuentro: Documents From the 1996 Encounter for Humanity and Against Neoliberalism, New York: Seven Stories Press 